\title{
RECORDING AND PUBLISHING OF MARRIAGE BOOK IN ORDER TO PREVENT UNREGISTERED MARRIAGE IN BATANGKUIS DISTRICT
}

\author{
Idha Aprilyana Sembiring ${ }^{1)}$, Zulfi Chairi ${ }^{2}$, Aflah $^{3)}$ \\ ${ }^{1)}$ Faculty of Law, Universitas Sumatera Utara, Medan, 20155 \\ Email: idhasemb@gmail.com \\ ${ }^{2)}$ Faculty of Law, Universitas Sumatera Utara, Medan, 20155 \\ Email: idhasemb@gmail.com \\ ${ }^{3)}$ Faculty of Law, Universitas Sumatera Utara, Medan, 20155 \\ Email: idhasemb@gmail.com
}

\begin{abstract}
This community empowerment and development program aims to increase public awareness, especially marriage couples in Batangkuis District in legalizing their marriages. Basically, the couples have known the necessity of registering marriages, but do not register for various reasons. They do not have a marriage book even though they have been married for a long time.To achieve this goal, two (2) phases of activities were carried out, (1) Legal counseling carried out for two days in two partner villages with the theme of the introduction, usefulness and benefits of marriage registration and legal consequences arising from not registering marriages and to (2) assistance activities in making marriage books. The targets are couples in the two partner villages who have long been married religiously but have not registered marriage. After legal counseling about the benefits and importance of marriage registration, there was an enthusiasm to ask for assistance in recording their marriages because most of the couples had been married for a long time and had many children but had no evidence of legality of their marriage. The enthusiasm of the husband and wife shows the approach through legal counseling is effective to move their legal awareness to register their marriages.
\end{abstract}

Keywords: Assistance, Marriage Registration, Marriage Book, Prevent,Unregistered Marriage.

\section{INTRODUCTION}

Marriage is a physical and spiritual bond between a man and a woman as husband and wife to form a happy and eternal family based on the One God Almighty, according to Article 1 of the Marriage Law No. 1 of 1974. Therefore, when going to get married there will be rules and requirements so that the marriage can be done, one of which is related to marital validity issues. Marriage is valid if it is carried out according to the law of each religion and belief (read Article 2 (1) of the UUP, but it is also regulated in Article 2 (2) of the UUP that each marriage must be registered according to the applicable legislation. It is clearly regulated that a marriage is only valid if it is done first according to the law of each religion and belief, after that a marriage registration is held. (Hilman, Hadikusuma: 2007)
The implementation of this marriage recording activity is contained in the provisions of Article 2 of Government Regulation (PP) Number 9 of 1975 concerning Implementation of Law Number 1 of 1974 concerning Marriage, as follows (Mohd. Idris, Romulyo: 1996):

1. Marriage registration of those who hold their marriage according to the Islamic Religion is carried out by the Registrar as referred to in Act Number 32 of 1954 concerning Registration of Marriage, Divorce and Referral.

2. Marriage records from those who hold their marriages according to their religion and beliefs other than Islam, are carried out by the Marriage Registration Officer at the Civil 
Registry Office as referred to in various laws concerning marriage registration.

One of the initial frameworks for obtaining legal guarantees in a marriage is to register the marriage to the authorized agency. Marriage registration is very important, because it has juridical implications in various aspects as a result of the marriage. However, in Indonesia there are several factors, especially those related to cultural and religious values or beliefs, which are obstacles to the implementation of marriage registration. (Research on Marriage Problems in the Community, Deli Serdang District Study: 2013)

Juridical facts (das sollen) and real facts (das sein) which become the foundation and which are at the same time as a basic of thinking to discuss sociological phenomena from the problem of marriage registration in Indonesia are: (Neng Djubaedah: 2010)

1. Juridical Facts (das sollen), which include:

a. Article 2 paragraph (2) of Law Number 1 of 1974 concerning Marriage, which reads: "Every marriage is recorded according to the prevailing laws and regulations".

b. Article 13 Government Regulation Number 9 of 1975 concerning Implementation of Law Number 1 of 1974 concerning Marriage, which reads:

(1) "The marriage certificate is made in duplicate 2 (two), the first piece is kept by the Registrar, the second piece is deposited with the Court Clerk in the area where the marriage registry is located".

(2) "To each husband and wife, a marriage certificate is given".

c. Article $5-6$ Compilation of Islamic Law (KHI / KompilasiHukum Islam) in Indonesia, which reads:
Article 5 provisions which read:

a. "To be guaranteed order for the Islamic community every marriage must be recorded".

b. "The marriage registration referred to in paragraph (1) is carried out by the Marriage Registration Officer as stipulated in Act Number 22 of 1946 in conjunction with Law Number 32 of 1954".

The provisions of Article 6 which read:

a. "To fulfill the provisions in article 5 , every marriage must be held before and under the Marriage Registration Officer".

b. "Marriage conducted outside the supervision of the Marriage Registrar does not have the force of law".

2. Real fact (das sein), which is difficult to expect legal awareness of some Indonesian people to have the awareness to carry out marriage records that have been carried out. In connection with the issue of recording this marriage, in practice there are still many bridal couples who hold marriages according to their respective religious law but have not registered the marriage. There are several reasons that cause the married couple not to register their marriage at KUA or at the Civil Registry office, among others, as follows: (Community service: 2017)

1. The couple did not know the legal provisions that a marriage must be registered.

2. Not aware of the legal consequences caused if the marriage is not registered.

3. Do not have fees to take care of marriage records.

4. Do not have the ability to complete administrative requirements that must be completed by the couple who will hold the marriage. 
Recording is one form of orderly administration as a modern state. Not only as an administration, marriage registration also guarantees the fulfillment of civil rights in the eyes of the law. For the sake of this orderly administration, the government also threatened people who did not register their marriages with a one-month imprisonment or a maximum fine of $\mathrm{Rp}$. 7,500 . However, this threat is ignored by citizens. There are still many people who do not register their marriages. This can be seen from research conducted by the Ministry of Religion. The study was conducted in several locations, namely Indramayu, Tangerang, Yogyakarta, Malang and Bangkalan Regencies. From each of these locations, the Ministry of Religion found that data on thousands of marriages were not recorded. In Bangkalan, from 2009-2012, 1.156 marriages were not recorded. A total of 1.144 marriages were not recorded found in Indramayu during 2010-2012. For Malang and Tangerang, there were 756 and 300 marriages during 2010-2012. While in Yogyakarta, since 2010-2012 there were only six cases. One indicator that is used for this data is the number of its marriage licenses. (Hukum Online.com:2012)

Likewise, what happened in Batangkuis Subdistrict. Batangkuis Subdistrict are dominated by people from Javanese (majority), Malay, with the majority religion adopted is Islam. Based on the preliminary survey, there were husband and wife couples who were married under Islamic religious law, but were not or were reluctant to register their marriages for a variety of reasons including incompetence in terms of marriage fees, or also due to the thought pattern married by means of religious law alone shows the legality of the marriage they are directing, besides that it is also found because of ignorance solely due to lack of knowledge about the importance of marriage registration.
From the results of this preliminary survey, the topic or issue that will be raised in this activity is identified as how efforts can be made for marriage registration assistance as well as the publication of marriage books for married couples who have been married religiously for a long period of time. The short-term objectives of this activity are assistance to register marriages and also publish marriage books, while the long-term goal is to increase legal awareness through the establishment of legal-conscious community groups so that they can be socialized more effectively especially for married couples who have not married but not yet registered marriage, to understand the purpose and benefits of marriage registration.

\section{PROBLEMS}

The problem faced by the community in Batangkuis Subdistrict is a problem related to marriage registration activities. Husband and wife couples have long been married, but only religiously. This happens because the people in these two villages have an inherent nature of religion, so that religious marriage is enough for them. But on the other hand, the absence of marriage books creates new problems for them during childbirth and also during inheritance. Based on this condition, the priority targets of community empowerment in this activity are as follows:

a. Increased insight and knowledge for husband and wife couples on their rights as citizens to legalize their marriage in religious and State law in accordance with the Marriage Law No. 1 of 1974.

b. Establishment of law-conscious community groups.

Through the establishment of a lawconscious community group, it is hoped that it can makethe community aware of the procedures carried out to obtain their rights to the legality ofmarriages carried out. Furthermore, the legal-aware community groups 
formed can facilitateconsultation services about it.

c. The community knows the functions and benefits of marriage registration.

d. Changes in mindsetof husband and wife about the importance of marriage registration, so that they can understand what efforts can be taken by the community.

e. Assistance in arranging marriage records for couples who will get married but have not registered their marriages

f. Provision of marriage books for couples whose marriages have been registered locally.

\section{METHODS}

\subsection{Type of Method}

The implementation of the partner village development program (PPDM/Program Pengembangan Desa Mitra) is divided into two (2) activities namely counseling and increasing understanding of the importance of marriage books for couples who are married and will be married. The description of these two activities is as follows :

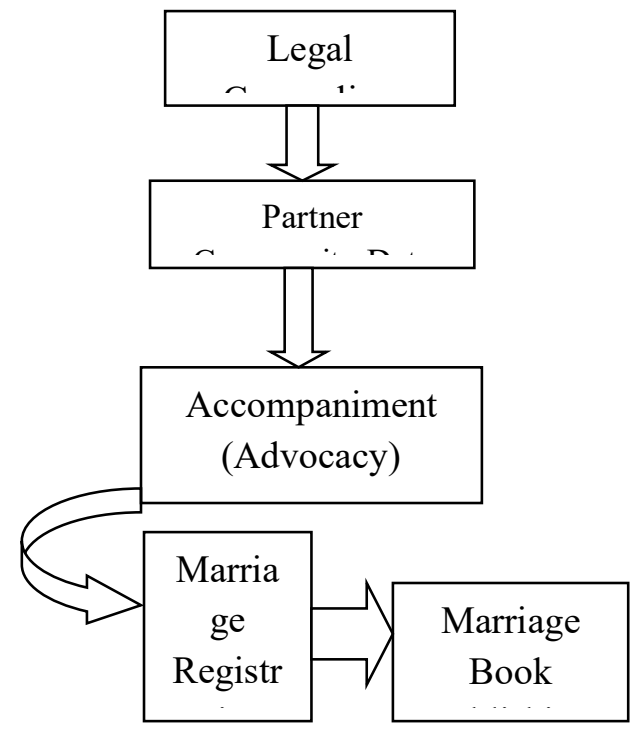

Figure 1. Community Service Methods in Batangkuis Sub-district
The explanation of the picture above is as follows:

a. Legal counseling was carried out for two (2) days in two (2) villages namely Sugiharjo Village and Sidodadi Village, with a total extension time of six (6) hours in each village. Partners send 40 (forty) in each village. Legal counseling is carried out in the Office of the Village Head, with the main material being the importance of marriage registration as a form of fulfilling rights and obligations as Indonesian citizens in accordance with the provisions of the law. Five people from each partner village will be empowered to form legal awareness groups.

b. Partner community data collection

After conducting legal counseling, the results achieved were the emergence of enthusiasmfrom the community, especially husband and wife who had been married for a long time butdid not have a marriage book. Based on the response from this community, the continuationof legal counseling activities is to collect data on couples who will be accompanied formarriage book registration and publication, which is reserved for married couples who havelong been married but do not have a marriage book. In the end, there were 12 husbands andwives from two (2) partner villages. Constraints faced in data collection and collection of thenumber of couples who will be accompanied in the recording and publishing of this marriagebook is located in the factor of availability of funds and also the factors of the communityitself which is reluctant or ashamed to be recorded, although basically they are in desperateneed of marriage books.

c. Assistance for recording and publishing marriage books

The accompaniment of assistance in the registration and publication of 
marriage books wascarried out from the end of August 2018 and completed in early September. The first phaseof the marriage book submission was carried out on 3/9/2018 directly to the husband andwife in the Village Head Office in the partner village which was witnessed by the Head ofKUA and his staff. Phase II submission of the marriage book will be carried out again at theend of September 2018 in the partner village.

\subsection{Data Collection Technique}

Data collection techniques are carried out by library research (document research) and field studies (filed research). Literature study was conducted to open discourse related to the topic of discussion based on literacy sources. While the field study was conducted to collect data on husband and wife couples who have been married for a long time, but do not have a marriage book. In addition, this field study was also assisted by informants in this case the village head of each partner village and also a very large share of Kadhinikah and Head of the Office of Religious Affairs (Kantor Urusan Agama) in Batangkuis District.

\subsection{Data Analysis}

Data analysis is carried out qualitatively, while conclusions are drawn in a deductive way which is drawing conclusions based on general data for later more detailed and specific.

\subsection{Location, Time and Duration of Activities}

The location of the service activities was carried out in BatangKuisSubdistrict, Deli Serdang Regency, which began in May October 2018.

\section{FINDINGS AND DISCUSSION}

\subsection{Activity I : Legal Counseling About The Benefits and Importance of Marriage Registration}

This service activity begins with holding a meeting with the village head at the service location to communicate and get support from the village head in order to facilitate the service activities. In this meeting, it was stated that the implementation of community service activities for the first year will be carried out in the form of two activities, namely legal counseling about the importance and benefits of marriage registration for couples who are going to marry and for those who are married but do not have a marriage book. A description of this service activity can be seen in the table below:

Table1 : Agenda of Community Service Activities in Batangkuis Sub-district

\begin{tabular}{|c|c|l|c|}
\hline $\begin{array}{c}\text { N } \\
\text { O }\end{array}$ & $\begin{array}{c}\text { DATE } \\
\text { OF } \\
\text { ACTIV } \\
\text { ITY }\end{array}$ & $\begin{array}{l}\text { DESCRIP } \\
\text { TION } \\
\text { OF } \\
\text { ACTIVITI } \\
\text { ES }\end{array}$ & $\begin{array}{c}\text { INFORMA } \\
\text { TION }\end{array}$ \\
\hline 1. & $\begin{array}{c}29 / 5 / 20 \\
18\end{array}$ & $\begin{array}{l}\text { Held } \\
\text { meetings } \\
\text { with village } \\
\text { heads from } \\
\text { both } \\
\text { service } \\
\text { locations }\end{array}$ & - \\
\hline 2. & $5 / 6 / 201$ & $\begin{array}{l}\text { Conducting } \\
\text { cooperation } \\
\text { with KUA } \\
\text { Batangkuis } \\
\text { District to } \\
\text { help } \\
\text { organize } \\
\text { marriage } \\
\text { registration } \\
\text { activities }\end{array}$ & \\
\hline 3. & $3 / 7 / 201$ & $\begin{array}{l}\text { Legal } \\
\text { councel } \\
\text { about the } \\
\text { importance }\end{array}$ & \\
\hline
\end{tabular}




\begin{tabular}{|c|c|c|c|}
\hline & & $\begin{array}{l}\text { of marriage } \\
\text { registration }\end{array}$ & \\
\hline 4. & $\begin{array}{c}4-14 \\
/ 7 / 2018\end{array}$ & $\begin{array}{l}\text { Data } \\
\text { collection } \\
\text { of married } \\
\text { couple, but } \\
\text { do not have } \\
\text { a marriage } \\
\text { book }\end{array}$ & $\begin{array}{l}\text { A total of } 12 \\
\text { (twelve } \\
\text { pairs) were } \\
\text { taken from } 2 \\
\text { (two) } \\
\text { partner } \\
\text { villages }\end{array}$ \\
\hline 5. & $\begin{array}{c}\text { Early } \\
\text { August } \\
2018\end{array}$ & $\begin{array}{l}\text { Inventory } \\
\text { of married } \\
\text { couples } \\
\text { chosen to } \\
\text { receive } \\
\text { assistance }\end{array}$ & \\
\hline 6. & $\begin{array}{c}\text { Mid } \\
\text { August } \\
2018\end{array}$ & Filing & \\
\hline 7. & $\begin{array}{c}\text { End of } \\
\text { August } \\
2018\end{array}$ & $\begin{array}{l}\text { Marriage } \\
\text { registration } \\
\text { process and } \\
\text { marriage } \\
\text { book } \\
\text { publishing }\end{array}$ & $\begin{array}{l}\text { By KUA } \\
\text { Batangkuis } \\
\text { District }\end{array}$ \\
\hline 8. & $\begin{array}{c}3 / 9 / 201 \\
8\end{array}$ & $\begin{array}{c}\text { Submission } \\
\text { of marriage } \\
\text { book } \\
\text { (Stage I) in } \\
\text { I (first) } \\
\text { mitra's } \\
\text { Village }\end{array}$ & $\begin{array}{l}\text { By the } \\
\text { Service } \\
\text { Team } \\
\text { assisted by } \\
\text { KUA, } \\
\text { Village } \\
\text { Heads and } \\
\text { Kadhi }\end{array}$ \\
\hline 9. & $\begin{array}{l}\text { Early } \\
\text { October } \\
2018\end{array}$ & $\begin{array}{c}\text { Submission } \\
\text { of marriage } \\
\text { books } \\
\text { (Stage II) } \\
\text { in II } \\
\text { (second) } \\
\text { mitra's } \\
\text { Village }\end{array}$ & $\begin{array}{l}\text { By the } \\
\text { Service } \\
\text { Team } \\
\text { assisted by } \\
\text { KUA, } \\
\text { Village } \\
\text { Heads and } \\
\text { Kadhi }\end{array}$ \\
\hline
\end{tabular}

Legal counseling activities were carried out through targeted discussions which began with lectures and then proceed with direct question and answer regarding the Act No.1 of 1974 concerning Marriage which aims to improve the knowledge and knowledge of the community, especially new couples who will marry in the two villages about the benefits of the importance of marriage registration and legal consequences that will arise if no marriage is registered. This activity was held on May 29, 2018. At the time this activity was held, the extension participants were very enthusiastic in following the course of the activity. This can be seen from the many questions raised by the community as counseling participants. For the questions asked by the participants, the training team tried to provide a thorough explanation so that the participants understood and felt satisfied with the answers and explanations given. After the extension activities were carried out, then continued data collection of married couples for assistance in recording and publishing marriage book.

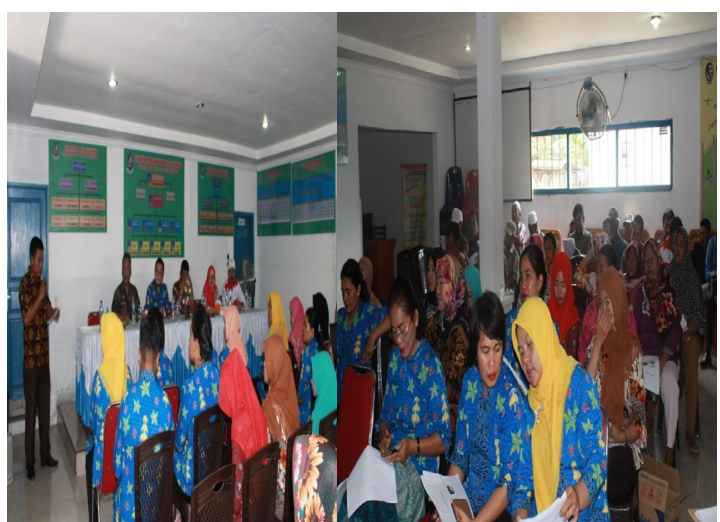

Figure 2. Legal Counceling Activities in the Village Head's Office

There is cooperation given by villagers, especially the Village Head. The Village Chief Authority directed the participants to come to this extension activity. In addition the material presented felt directly beneficial for the village community. The hospitality of the participants in the extension activities so that they can be invited to communicate and have a high level of curiosity is due to the development of technology that enables them to have more understanding, especially related to legal protection for the marriage they form someday, so that this extension activity needs to be continued continuously in the future as a manifestation of the Tri Dharma of Higher Education. In addition, good assistance and cooperation were also 
obtained from the Head of KUA, Batangkuis Subdistrict and Kadhi Nikah from each partner village. While the weaknesses found in this service are the emergence of several obstacles related to time constraints. In addition, other aspects are the difficulty of the participants to leave their jobs and the distance of the house is quite far from the place of activity, so that it is difficult to bring the trainees in a larger number. Paying attention to the purpose and benefits of this extension activity is to increase the knowledge and insight of the community, especially for couples who are going to get married in understanding the marriage law applicable in Indonesia in connection with marriage registration activities and understanding the legal consequences that will arise for married couples without carrying out marriage records, the implementation of this extension activity was quite successful. This can be proven from the responses of the counseling participants who were very enthusiastic in asking questions in the question and answer session on counseling materials that were poorly understood. In addition, the village government through the Village Head requested that on another occasion a legal counseling team from the USU Faculty of Law / LPPM would come back to provide counseling for the community in the village.

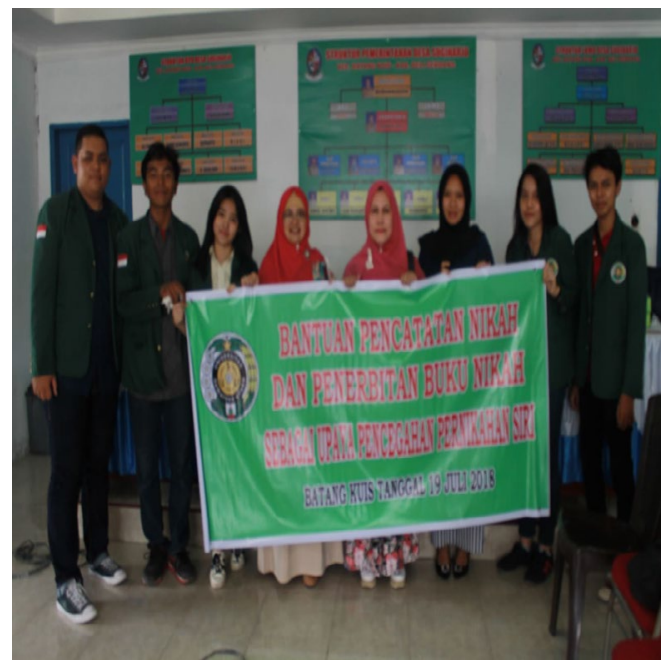

Figure 3. Community Service Team
The counseling material that has been compiled in the form of power point slides and printed allows it to be re-read and discussed together on other occasions, even the benefits that are felt can be wider to the community because those who have not had the opportunity to attend these counseling activities can understand and learn it by reading it themselves. As for the substance of the material presented are:

1. Understanding Marriage Registration Marriage registration is an effort that aims to realize marital order in society. With the intention of being able to be used whenever necessary and can be used as authentic evidence.

2. Legal basis for marriage registration Article 2 (2) of Law NO. 1/1974 concerning Marriage, which reads: "Every marriage is recorded according to the applicable regulations"

4. Benefits and importance of marriage registration

5. Requirements in making marriage books. The requirements that must be fulfilled at the time of marriage registration are as follows: (Wahyu Ernaningsih: 2013)

a. Photocopy of proof of marriage validation according to religion by bringing the original

b. Photocopy of quotation of birth certificate with the original.

c. Photocopy of Family Card and Identity Card (KTP/KartuTandaPenduduk) with the original.

d. Photocopy of divorce certificate or death certificate quote for those who have ever married.

e. For groom/brides who are under 21 years of age there must be permission from the parents, if at the time of the marriage the parents are unable to attend, there must be an official permit known by the authorized official 
f. District Court permit for prospective groom/brides under the age of 21 , if they do not get approval from parents.

g. District Court permit if the prospective groom is under the age of 19 and the bride is under 16 years.

h. Decree of the District Court that has certain legal force if there is a rebuttal.

i. Permission from the District Court for polygamy.

j. Camat Dispensation if the marriage registration is less than ten days from the date of filing the application.

k. Excerpt of Birth Certificate of Child that will be recognized / endorsed in marriage, if any.

1. Announcement results that have no objections.

$\mathrm{m}$. Deed of separate marriage property agreement if both bride and groom want and must be legalized by the registrar at the Civil Registry Office.

n. For those under the age of 21, there must be a permit from the Heritage Property if the parent dies by attaching the death certificate of his parents.

o. For TNI members a permit from the commander.

p. For Indonesian Citizens to attach a copy of: a. Proof of Citizenship of the Republic of Indonesia. b. Proof of name change (if you have changed your name)

q. For foreigners attach a photocopy of:

a. Passport

b. Immigration document

c. Self Reporting Certificate (STMD)

d. Permission from the Embassy / representative from a friend's country, specifically Taiwan from the Chamber of Commerce and other countries that do not have representation must have a recommendation from the Ministry of Foreign Affairs c.q. Director General of Protocol and Consular.

e. Along with $4 \times 6 \mathrm{~cm}$ size photos alongside 4 sheets.

f. Two witnesses who met the requirements

6. The marriage recording scheme for those who are married but has not registered a marriage. As for the marriage registration scheme for those who are married, are as follows:

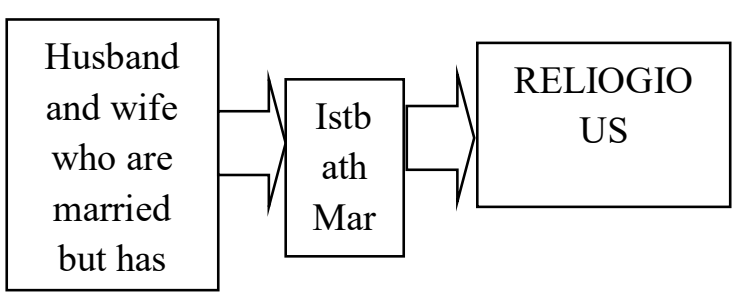

Figure 4. Scheme of Marriage Registration for Husbands and Wives who have been married but not registered

7. Understanding and introduction to istbath marriage and the reasons for istbath marriage are held, as stated below:

Istbath may only be submitted for problems:

a. In the context of divorce

b. Missing Deed

c. There are doubts about the validity of one of the terms of marriage

d. For marriages held before the enactment of Act No.1 of 1974

e. Marriage is done for people who have no obstacle to marry

\subsection{Activity II :Data Collection of Husband and Wife in the Two Partner Villages}

The second activity carried out is data collection for married couples who have been married for a long time but do not have a marriage book. In this activity, an inventory of married couples will be 
assisted to record marriages and obtain marriage books.

This data collection and inventory of married couples who do not yet have a marriage book is carried out in collaboration with the Village Head, KUA Chief of BatangkuisSubdistrict and also with assistance from KadhiNikah from the two partner villages. When the data collection was carried out, it took quite a long time for more than 1.5 (one and a half) months, due to several obstacles encountered during the data collection and re-filing. This occurs due to several factors, such as:

a. The husband and wife forget their date of marriage.

b. Many marriage witnesses have died.

c. The absence of an identity card such as a KTP, either because it is lost or damaged.

d. Documentation from husband and wife which have been lost or damaged.

e. The shame and reluctance of a husband and wife to get help recorded their marriage because of marital conditions that had been very long and also because they already had a grandchildren.

However, in the end this problem could be resolved and there were only 12 (twelve) husband and wife pairs from both villages, because these twelve pairs could fulfilled the requirements of many couples who submitted a request.

\subsection{Activity III : Marriage Registration Assistance and Marriage Book Handover}

The third activity is assistance in marriage registration and marriage book publishing. After obtaining data on 12 (twelve) married couples who will be accompanied to make a marriage registration, then proceed with the filing of data and payment of marriage billing amounting to Rp.600,000 (six hundred thousand Rupiah) through PT POS
Kota Medan. In accordance with the provisions of Government Regulation No. 9 of 1975 concerning Implementers of Law No. 1 of 1974, a new marriage book will be issued no later than 10 (ten) days after the registration and billing payment.

Right on September 1, 2018, there were 8 (eight) of the 12 (twelve) marriage books completed. The eight completed marriage books are for married couples who live in Sugiharjo Village, so the first stage of the marriage book submission is done on Monday, September 3, 2018, the marriage book is handed over at the Sugiharjo Village Head's Office, as shown in the pictures below:
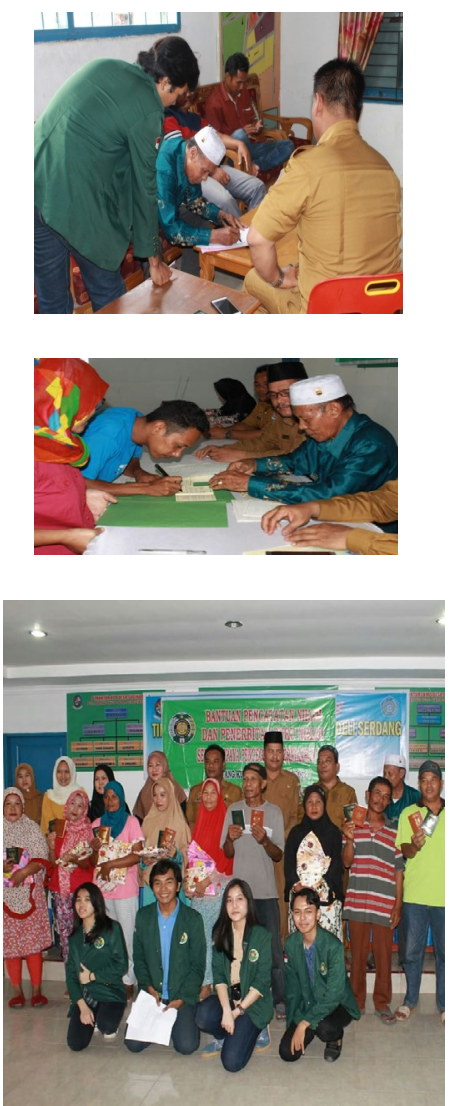

Figure 5. Marriage Book Submission Day at the Office of the Village Head of Sugiharjo 

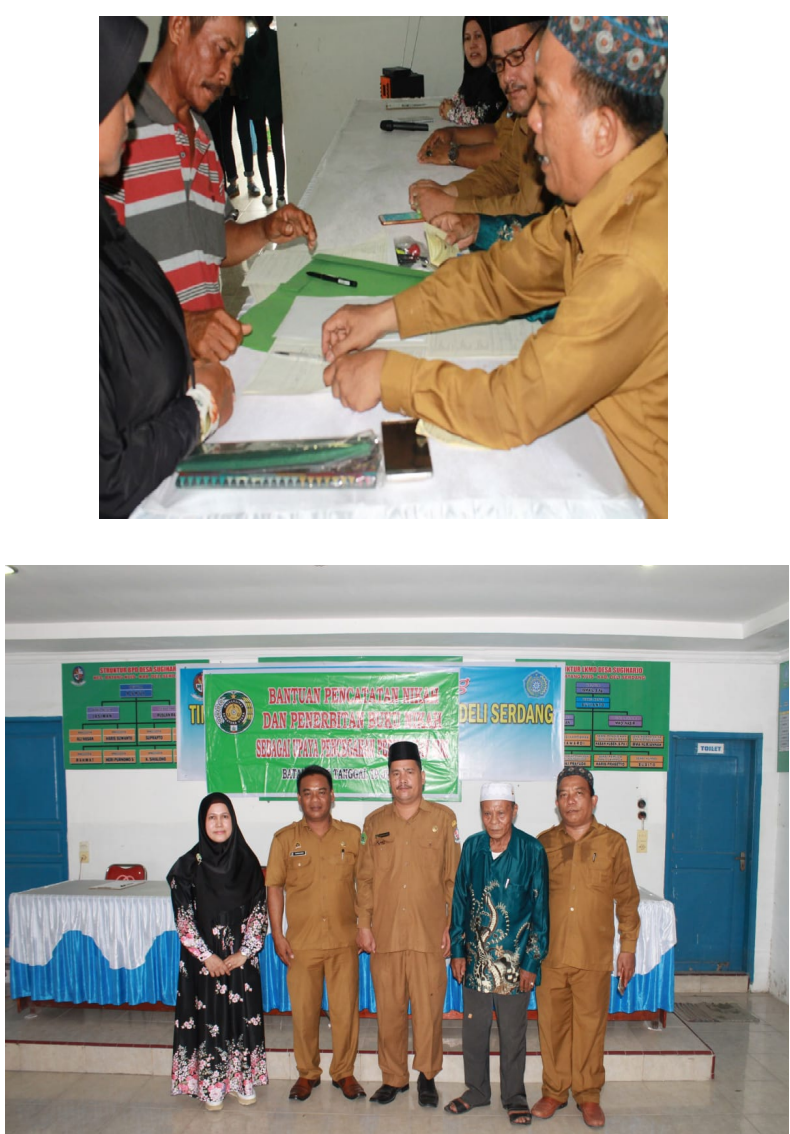

Figure 6. Community Service Team with Head of KUA, Village Head and Kadhi Nikah

\subsection{Follow-Up Activities}

Further activities that will be carried out next are :

Table 2 : Follow-up Activities

\begin{tabular}{|c|c|c|}
\hline No & Activity & Information \\
\hline 1. & $\begin{array}{c}\text { Second stage } \\
\text { marriage book } \\
\text { submission for } \\
\text { husband and } \\
\text { wife couples in } \\
\text { Second mitra's } \\
\text { Village }\end{array}$ & $\begin{array}{c}\text { Scheduled for } \\
\text { early October }\end{array}$ \\
\hline 2. & $\begin{array}{c}\text { Establishment } \\
\text { of Legal } \\
\text { Awareness } \\
\text { Group from the } \\
\text { two partner } \\
\text { villages }\end{array}$ & \\
\end{tabular}

The follow-up activities that will be carried out soon are the second stage of the marriage book submission for married couples in the second partner village. The advanced follow-up activities are the establishment of a Legal Awareness Society that will be trained to socialize and help educate the surrounding community to understand the law, especially when they are going to marry.

\section{CONCLUSION}

1. The knowledge and understanding of community in the two partner villages regarding the necessity of marriage registration is good enough, but in practice they still have to get more intensive guidance.

2. Community legal awareness in the two partner villages to register marriages still needs guidance and monitoring. Community partners recognize the importance of recording but sometimes neglect in its implementation caused by various factors including economic, educational, cultural. For couples who already have a marriage book sometimes do not care about the existence of marriage books, so sometimes marriage books are lost or destroyed.

3. After being socialized and held legal counseling, the community in the partner village responded well enough to bring back the legal awareness to immediately have a marriage book.

\section{ACKNOWLEDGMENT}

We would like to thank the Rector of University of Sumatera Utara for funding this project through a Program Pengabdian Tahun 2018 scheme. In addition, our sincere thank also goes to the Community Service Institute of the University of Sumatera Utara for the facilities during the completion of this project. 


\section{REFERENCE}

Djubaedah, Neng, 2010, Pencatatan Perkawinan dan Perkawinan Tidak Dicatat, Jakarta :Sinar Grafika.

Ernaningsih, Wahyu,2013.Pentingnya Pencatatan Perkawinan Menurut UU no 1 Tahun 1974 Tentang Perkawinan, Yogjakarta

Hadikusuma, Hilman,2007. Hukum Perkawinan Indonesia menurut Perundangan, HukumAdat, Hukum Agama, MandarMaju. Bandung.

Harahap, M.Yahya,1975. Pembahasan Hukum Perkawinan Nasional, CV.Zahir. Medan.

Romulyo, Mohd. Idris,1996. Hukum Perkawinan Islam: Suatu Analisis dari UU No.1/1974 dan KHI, BumiAksara, Jakarta.

S. Meliala, Djaja, 2008. Himpunan Peraturan Perundang-undangan tentang Perkawinan, NuansaAulia. Bandung

Syamsul, Bahri, 2012, Pelaksanaan Pencatatan Pernikahan di Kecamatan Medan Labuhan Kota Medan, Pascasarjana UIN Sumatera Utara

\section{Other reference :}

Research-based service entitled "Pemberdayaan Masyarakat melalui Pembuatan Akta Nikah bagi Perkawinan yang Tidak Tercatat di Desa Bangun Mulia dan Timbang Deli, Medan Amplas. Medan.”2017.

Research entitled“ Problematika Perkawinan di Masyarakat, Studi Kabupaten Deli Serdang"2013.

Hukum online.com 30/12/2012 accessed on September 25, 2018 